\title{
Investigation of the effect of fabric properties on the fabric use efficiency
}

\section{REZUMAT - ABSTRACT}

\section{Investigarea efectului proprietăților țesăturii asupra eficienței în utilizare}

Există mai mulți factori care afectează eficiența utilizării țesăturilor, unul dintre aceștia fiind proprietățile țesăturilor. Utilizarea diferitelor țesături pentru confecționarea aceluiași produs crește sau scade cantitatea de țesătură necesară, ceea ce afectează costul produsului. În acest studiu, a fost investigat efectul proprietăților țesăturii asupra eficienței utilizării țesăturilor. Pentru procesele de aplicare au fost utilizate 3 proprietăți diferite ale țesăturilor și 3 articole de îmbrăcăminte diferite și au fost elaborate în total 9 marker planuri. Analizând marker planurile pregătite, au fost obținute rapoartele de utilizare a țesăturii și a fost investigat efectul proprietăților țesăturii asupra eficienței utilizării acestora.

Cuvinte-cheie: proprietățile țesăturii, eficiența utilizării țesăturii, marker plan

\section{Investigation of the effect of fabric properties on the fabric use efficiency}

There are several factors affecting fabric usage efficiency, one of them is fabric properties. The usage of different fabrics for production of the same product increases or decreases the amount of fabric needed, which affects the cost of the product. In this study, effect of fabric properties on the fabric usage efficiency was investigated. For the application processes, 3 different fabrics properties and 3 different garments were used and totally 9 marker plans were prepared. By analyzing the prepared marker plans fabric usage ratios were obtained and effect of fabric properties on the fabric usage efficiency was investigated.

Key-words: fabric properties, fabric usage efficiency, marker plan

\section{INTRODUCTION}

Cost is the most important element in making product decisions. Cost is the main subject in companies. Because the savings in production without compromising on quality will positively influence costs, using all kinds of material, system, and manufacturing time should be the main purpose. When cost structure of apparel products is analyzed, it is seen that fabric and accessories subscribe $50-60 \%$ of product costs [1]. Increasing the efficiency of the fabric usage which is one of the most important inputs of the ready-made garment production decreases the product cost. Prediction, planning and control of the waste are very important for the ready-made garment companies, as they want to obtain maximal profit with minimal input. Therefore, the production cost of the companies decreases and their competitiveness increases [2]. The greater part of the readymade garment cost as being fabric, reveals the importance of the fabric waste [1]. A minor increase or decrease of the fabric waste highly affects the product cost. Therefore, the effective usage of the fabrics and minimized fabric waste positively affects the product cost.

Recent researches regarding the parameters that matter for fabric operation productivity indicate that it is affected by the CAD system usage [3-7], the imperfection of fabric width [4, 8-11], marker plan length, garment size and assortment size distribution $[1,11-12]$.
When the studies were investigated, it was seen that only fabric width was analyzed under the heading of fabric properties. In this study, different from the previous studies, effects of structural properties of the fabrics were investigated on fabric usage efficiency. The structural properties of the fabric used in garment production highly affect the fabric waste and therefore the product cost, which is the basis that determines how to place the pattern parts of the garment on the marker plan. For example, the manufacture of the same garment from the pile or figured fabric affects the fabric waste, therefore the garment cost.

In this study, three different featured fabrics and three different products were chosen and nine different marker plans were prepared with the same assortment and fabric width. Fabric properties' effects on fabric usage efficiency were observed via marker plans. The aim of the study is to reveal to what extent fabric properties effect on fabric usage efficiency and to provide an insight into production units.

\section{MATERIAL AND METHOD}

There are three products chosen for this study; t-shirt, shirt and trousers as seen in figure 1.

Three different marker plans were prepared for each of the products. In total nine marker plans were used to determine the fabric properties effects on marker plan productivity.

Three different fabric properties were considered on marker plans. There are: 
1. Fabric: The fabric was considered without any pile or figure. Thus, pattern parts of the products were placed in the desired direction of the fabric.

2. Fabric: The fabric was considered to have pile and pattern parts that compose the products were placed just in one direction.

3. Fabric: The fabric was considered to have both horizontal- and vertical-striped. Pattern parts of the products were placed as lines guzzle to each other, just in one direction.

The fabric width was considered as $170 \mathrm{~cm}$ for all marker plans. The assortment distribution was as follows in table 1.

Table 1

\begin{tabular}{|l|c|c|c|c|}
\hline \multicolumn{5}{|c|}{ ASSORTMENT PLAN } \\
\hline Sizes & 34 & 36 & 38 & 40 \\
\hline Assortment & 1 & 2 & 2 & 1 \\
\hline
\end{tabular}

The marker plans were prepared by Gerber operator with using Gerber Accumark V8 program. Marker efficiency values were taken from the Gerber system. Figures 1-3 show three different marker plans of the shirt, the t-shirt and the trousers respectively.

According to Glock and Kunz; marker efficiency is determined from fabric utilization, the percentage of total fabric that is actually used in garment parts [13]. For the calculation of the fabric usage efficiency from the marker plans, the ratio of the total pattern area to marker area is based on:

Fabric Usage Efficiency (FUE \%) = Total Pattern Area / Marker Area [5].

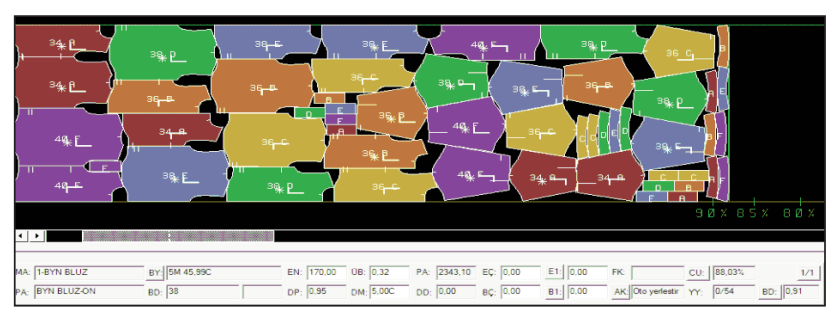

$\mathbf{a}$ - Marker plan prepared according to the $1^{\text {st }}$ fabric

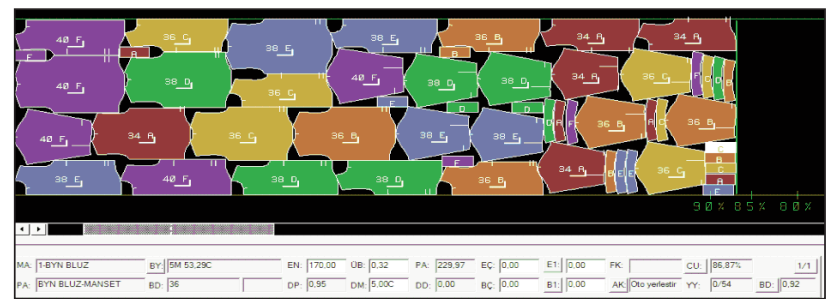

$\boldsymbol{b}$ - Marker plan prepared according to the $2^{\text {nd }}$ fabric

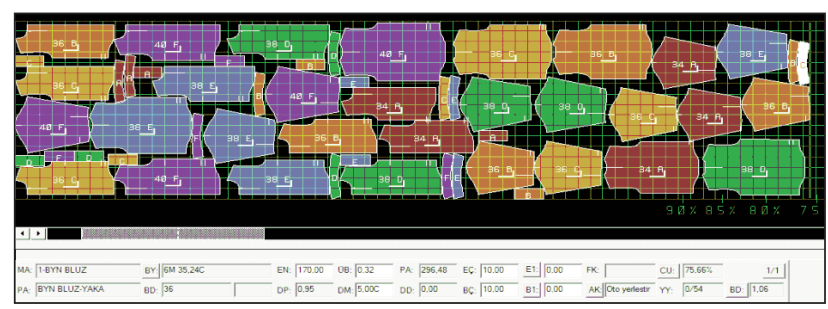

$c$ - Marker plan prepared according to the $3^{\text {rd }}$ fabric

Fig. 1. Three different marker plans of the shirt

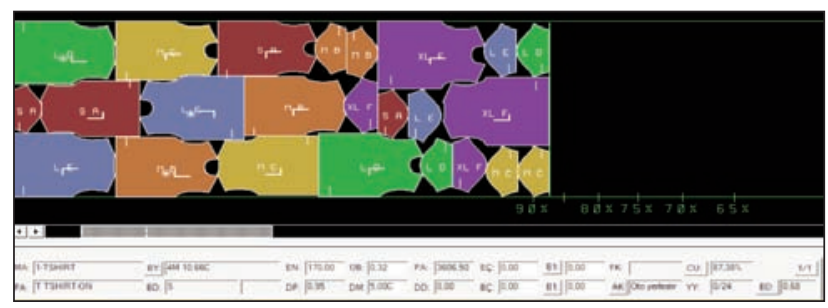

$\mathbf{a}$ - Marker plan prepared according to the $1^{\text {st }}$ fabric

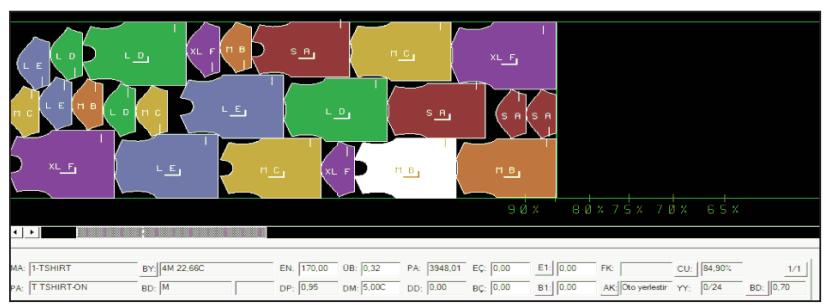

$\boldsymbol{b}$ - Marker plan prepared according to the $2^{\text {nd }}$ fabric

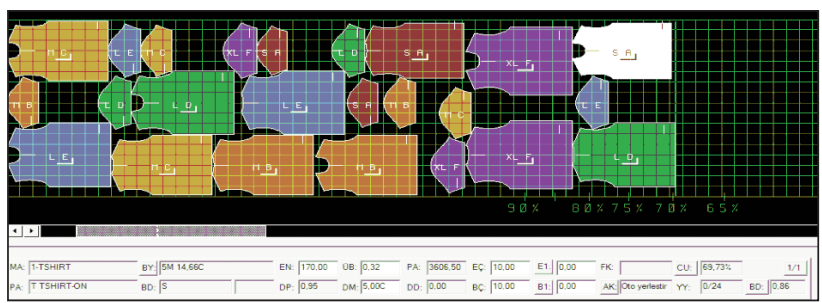

c - Marker plan prepared according to the $3^{\text {rd }}$ fabric

Fig. 2. Three different marker plans of the t-shirt

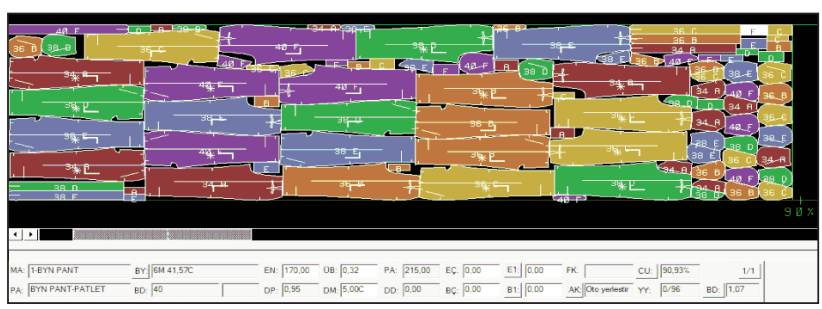

$\mathbf{a}$ - Marker plan prepared according to the $1^{\text {st }}$ fabric

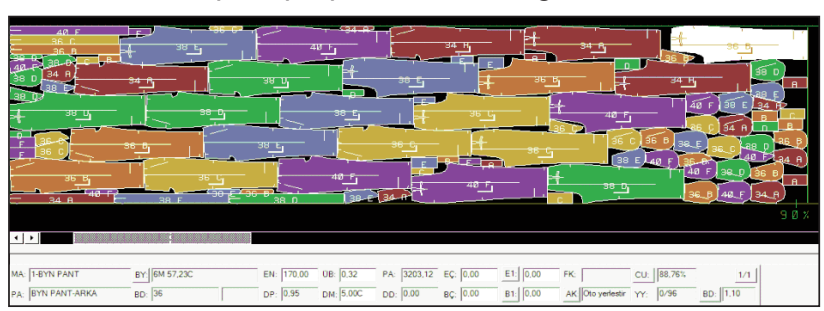

$\boldsymbol{b}$ - Marker plan prepared according to the $2^{\text {nd }}$ fabric

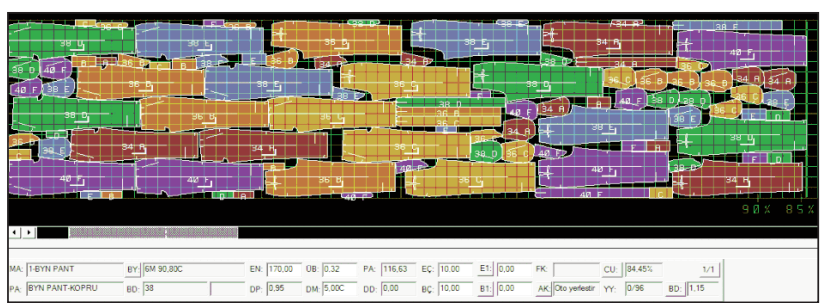

c - Marker plan prepared according to the $3^{\text {rd }}$ fabric

Fig. 3. Three different marker plans of the trousers

\section{RESULTS}

After the preparation of the marker plans, the results for fabric usage efficiency and fabric consumption are given in figure 4 and figure 5 . 


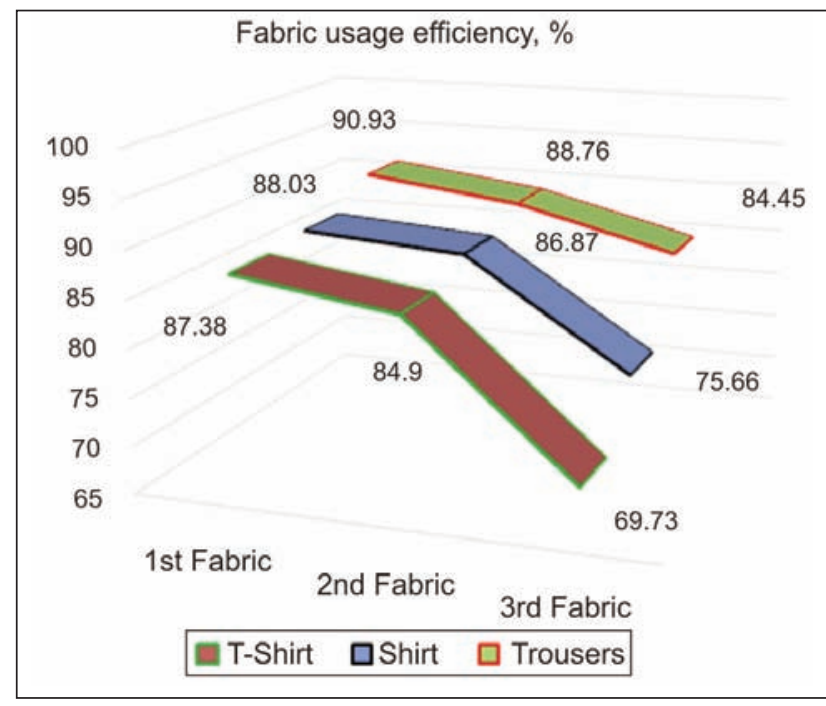

Fig. 4. Fabric Usage Efficiency (\%)

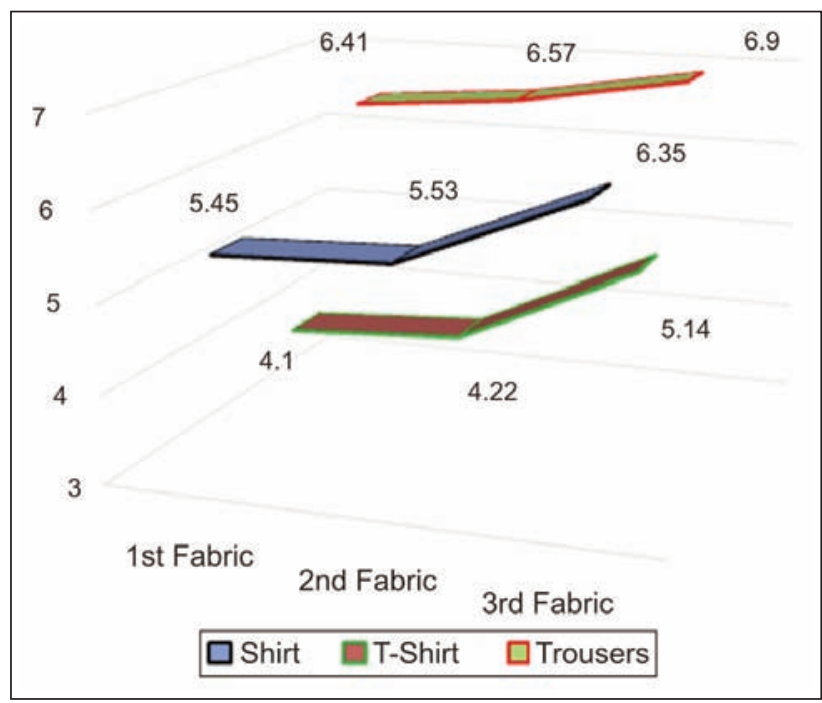

Fig. 5. Fabric Consumption (m)

Fabric usage efficiency of trousers was found $90.93 \%, 88.76 \%$ and $84.45 \%$ for first, second and third fabric in marker plans, respectively. On the other hand, fabric usage efficiency of shirts was found $88.03 \%, 86.87 \%$ and $75.66 \%$ for first, second and third fabric in marker plans, respectively. Whereas, fabric usage efficiency of $\mathrm{t}$-shirts was found $88.03 \%, 86.87 \%$ and $75.66 \%$ for first, second and third fabric in marker plans, respectively, as seen in figure 4 . In the light of these results, it was observed that fabric features affect the operational productivity of the fabric.

Fabric waste of trousers was found $6.41 \mathrm{~m}, 6.57 \mathrm{~m}$ and $6.90 \mathrm{~m}$ for first, second and third fabric in marker plans, respectively. On the other hand, fabric waste of shirts was found $5.45 \mathrm{~m}, 5.53 \mathrm{~m}$ and $6.35 \mathrm{~m}$ for first, second and third fabric in marker plans, respectively. Whereas, fabric waste of $t$-shirts was found $4.10 \mathrm{~m}, 4.22 \mathrm{~m}$ and $5.14 \mathrm{~m}$ for first, second and third fabric in marker plans, respectively, as seen in figure 5. In the light of these results, it was observed that fabric waste affects the operational productivity of the fabric.

When marker plan lengths were considered as seen in figure 5 , product based fabric consumption amount was shown in table 2 .

Fabric consumption for each garment is calculated using the formula shown below.

Fabric consumption $=$ Marker plan length $/$ Total size on marker plan.

Table 2

\begin{tabular}{|l|c|c|c|}
\hline \multicolumn{4}{|c|}{ FABRIC CONSUMPTION FOR EACH PRODUCT } \\
\hline Products & $\begin{array}{c}\mathbf{1}^{\text {st }} \text { Fabric } \\
{[\mathbf{m}]}\end{array}$ & $\begin{array}{c}\mathbf{2}^{\text {nd }} \text { Fabric } \\
{[\mathbf{m}]}\end{array}$ & $\begin{array}{c}\mathbf{3}^{\text {rd }} \text { Fabric } \\
{[\mathbf{m}]}\end{array}$ \\
\hline Trousers & 1.068 & 1.095 & 1.150 \\
\hline Shirt & 0.908 & 0.922 & 1.058 \\
\hline T-shirt & 0.683 & 0.703 & 0.857 \\
\hline
\end{tabular}

Fabric consumption by amount was observed as $1.068 \mathrm{~m}, 1.095 \mathrm{~m}$ and $1.150 \mathrm{~m}$ from the first fabric to third for pant, $0.908 \mathrm{~m}, 0.922 \mathrm{~m}$ and $1.058 \mathrm{~m}$ from the first fabric to third for shirt, $0.683 \mathrm{~m}, 0.703 \mathrm{~m}$ and $0.857 \mathrm{~m}$ from the first fabric to third for t-shirt respectively, shown in table 2. Relatively, it was observed that fabric waste affects the operational productivity of the fabric.

Results from figures $4-5$ and values from table 2 , the change of operational productivity of the fabric according to its feature and fabric consumption amount was analyzed as seen in table 3 .

As seen in table 3 , the change of operational productivity of the fabric between first and second fabrics were $1.32-2.83 \%$, between second and third fabrics were $4.85-17.86 \%$ and between first and third fabrics were $7.12-20.2 \%$ for all three products.

The change of fabric consumption amount between first and second fabrics were $1.46-2.93 \%$, between

Table 3

\begin{tabular}{|l|c|c|c|c|c|c|}
\hline \multicolumn{4}{|c|}{ EXCHANGE RATIO OF FABRIC USAGE EFFICIENCY AND FABRIC CONSUMPTION } \\
\hline
\end{tabular}


second and third fabrics were $5.02-21.80 \%$ and between first and third fabrics were $7.64-25.36 \%$ for all three products.

To conclude up, the change ratio of both operational productivity and the consumption amount of fabric showed an increase from the first fabric to third.

\section{CONCLUSION}

The aim of the study is to examine the effects of fabric properties on marker plan productivity, in parallel with the effects on product cost. For this purpose, three different fabrics which have different properties were chosen for three different garments and nine different marker plans were prepared. Results were evaluated for fabric usage efficiency and waste amount of the fabric.

At the end of this study, first fabric with no grain no figure was determined to have the highest operational productivity, whereas both cross- and the vertical-striped third fabric was determined to have the lowest operational productivity for all three products. Supportively, the lowest consumption was observed in first fabric, whereas the highest in third fabric.
These results revealed that the consumption amount of the fabric was highest in striped or figured fabrics compared to others. The reason is that when lines were needed to guzzle to each other, pattern parts of the products cannot be placed as desired.

The highest fabric consumption amount after the striped or figured fabrics was observed in grain fabrics. The reason is again the limitation to place pattern parts of the products to the marker plans. At this point, all of the pattern parts must be placed in the same direction.

Otherwise, grains on the fabric surface cause different color reflections occurrence.

Fabric features affect the consumption amount, operational productivity and also cost. If the same fabrics were used for the same products (fabric prices are ignored), product costs will vary. Therefore, fabric features must be taken into consideration while calculating the product cost.

By this study, effects of fabric features on operational productivities and consumption amounts of the fabrics were studied to point out especially for garment manufacturers.

\section{BIBLIOGRAPHY}

[1] Oral, O. Gömlekte Ölçü Değişiminin Kumaş Kullanım Miktarı Üzerine Etkisi, In: Tekstilve Konfeksiyon 23 (2), 2013.

[2] Kayar, M. Hazır Giyim İşletmelerinde Verimsizliği Ortaya Çıkaran Nedenlerin Araştırılmasıve Bunların Çözümüne Yönelik Alan Çalışması, PhD Thesis, Marmara University, Institute of Pure and Applied Sciences, Istanbul, 2008.

[3] Kozlov, B.A. Plotnıye mnogokomplektniye raskladki detaley şveynih izdeliy, legprombitizdat, p. 152, Moskva, 1985.

[4] Erdogan, M.C. Determination of ideal width of fabric to production of workers' dress. In: Tekstilve Konfeksiyon, nr. 6 , p. 621, 1991.

[5] Baykal, P.D., Gocer, E. The effect of fabric and model diversity to quality and productivity in Clothing Industry. In: Journal of Textiles and Engineer, vol. 19, pp. 15-23, 2012.

[6] Ondogan, Z., Erdogan, C. The comparison of the manual and CAD systems for pattern making, grading and marker making processes, In: Fibres \& Textiles in Eastern Europe, vol. 14, nr. 1, p. 67, 2006.

[7] Agac, S. Erkek Takım Elbise Üretiminde Kumaş Eni Farklııklarından Kaynaklanan Firelerin Tespitive Optimal Kumaş Eninin Belirlenmesi Üzerine Bir Araştırma. Msc. Thesis, Gazi University, Institute of Social Science, Ankara, 1995.

[8] Zak, S., Sizova, R.I., Kozlov, B.A. Hi-tekhnologii obespeçivayut ekonomiyu sirya do 6\%, In: Şveynaya promışlennost, pp. 26-33, Moskva, 2002.

[9] Kobilyanski, D.A. Sozdat progressivniye standarti na tkani, In: Legkaya promışlennost, nr. 7, pp. 15-18, 1958.

[10] Podolyakin, V.I. Avtomatizirovannıy kompleks rasionalnogo ispolzovaniya materialov na şveynom predpriyatii, In: Legprombıtizdat, p. 153, Moskva, 1987.

[11] Kayar, M., Dal, V., Mıstık, S.I. Investigating the effect of the marker assortment size distribution and fabric width on the fabric use efficiency, In: Industria Textila, vol. 66, nr. 3, 2015.

[12] Lebedeva, G.F. Opredeleniye rasionalnih dlin kuskov tkaney dlya verkney odejdi, In: Nit Sniişp, No. 29, pp. 16-19, Moskva, 1975.

[13] Glock, R.E., Kunz, G.I. Apparel manufacturing: Sewn product analysis, In: $4^{\text {th }}$ Edition Publisher: Pearson, 2004.

Authors:

\section{MAHMUT KAYAR ${ }^{1}$, NIHAN KIRAR ${ }^{2}$, ÖYKÜ CEREN BULUR ${ }^{3}$}

${ }^{1}$ Marmara University, Faculty of Technology, Department of Textile Engineering

${ }^{2}$ Marmara University, Institute of Pure and Applied Sciences, Department of Textile Education

${ }^{3}$ University, Institute of Pure and Applied Sciences, Department of Textile Engineering

Goztepe Campus, Kadıkoy 34722 Istanbul, Turkey

Corresponding author:

MAHMUT KAYAR

e-mail: mkayar@marmara.edu.tr 